\title{
10. ORGANIC GEOCHEMISTRY OF CRETACEOUS' SEDIMENTS AT DSDP HOLES 417D (LEG 51), 418A (LEG 52), AND 418B (LEG 53) IN THE WESTERN NORTH ATLANTIC
}

\author{
G. Deroo, J. P. Herbin, J. Roucaché, and B. Tissot, Institut Français du Pétrole, Rueil-Malmaison, France
}

\begin{abstract}
Mixed claystones and nannofossil chalks of late Aptian-Cenomanian age rested upon basaltic basement at DSDP Holes 417D, 418A, and 418B. Marine organic matter was largely preserved in the sediments. In addition, continental inputs of organic matter were rhythmically introduced, with detrital reworked material also present. Detrital material characterizes Upper Cretaceous sediments.
\end{abstract}

\section{INTRODUCTION}

The study was prepared to examine from a geochemical perspective the organic matter present in the Aptian to Cenomanian sediments penetrated by DSDP Holes 417D, 418A, and 418B (Figure 1) which rest directly on basalts.

Pyrolysis assay on the whole sample was followed by a chloroform extraction on some combined samples. As contamination was detected in the extracted hydrocarbon fractions, a new pyrolysis analysis was made on the extracted samples. Then a study of kerogen fractions was applied on some combined samples.

\section{SAMPLING}

Thirty-two samples of the Late Cretaceous and Cenomanian to Aptian from Hole 417D, 4 samples from Hole $418 \mathrm{~A}$, and 9 others from Hole 418B were collected. They belong to zeolitic multicolored clays of Late Cretaceous age or to various sequences of red-brown, green, and black claystones and nannofossil chalks of Cenomanian to Aptian ages (Figure 2).

\section{ANALYTICAL METHODS}

The analytical procedures are outlined in Figure 3. They were described in previous papers devoted to DSDP Leg 47 (Deroo et al., in press a, b) in the eastern North Atlantic.

\section{DETAILED RESULTS}

\section{Mineral Carbon}

As shown in Table 1, the Upper Cretaceous samples at Site 417 (Cores 417D-9 to 417D-16) contain a low to very low content of mineral carbon ( 0.00 to 1.00 wt. \%), and are composed of zeolitic clays. Cenomanian materials (Section 417D-17-1) to Albian (Sections 417D-17-2 to 417D-20-2) show a large range of variation $(0.60$ to $8.60 \%)$. The mineral carbon values can be divided into a carbonate fraction with more than 4 per cent mineral carbon found in the nannofossil chalks and limestones and a noncalcareous fraction (generally $<3 \%$ mineral carbon) contained in various clays and claystones. The Albian to Aptian samples (Sections 417D-21-1 to 417D-21-3) are mainly composed of claystone ( 1.52 to $2.88 \%$ mineral carbon).
At Hole 418A, the samples considered of Cenomanian to Aptian age belong to a clayey material poor in mineral carbon (0.08 to $1.32 \%)$.

At Hole 418B, a carbonate lithology designated as nannofossil chalk was found for Cretaceous Samples 418B-28-1, $106 \mathrm{~cm}$; 418B-28-1, $113 \mathrm{~cm}$; and 418B-33-1, 59 $\mathrm{cm}$; with 4.16 to 6.96 per cent mineral carbon. The various clays from Samples 418B-28-1, $101 \mathrm{~cm}$ and 418B-28-1, 118 $\mathrm{cm}$ and from Sections 418B-30-1 through 418B-30-3 contain a very low mineral carbon content ( 0.00 to $1.20 \%)$.

\section{Organic Carbon}

In Hole 417D, the zeolitic colored clays of Late Cretaceous age belong to a very organic-poor interval $(<0.15 \mathrm{wt}$. \%). Cenomanian to Aptian sediments exhibited two extremes: a poor organic content $(<0.15 \%)$, which corresponds to colored clays; and rich sediments ( $5 \%$ and more), the so-called black or dark organic claystones. Intermediate contents correspond to a material described as nannofossil chalk (Sections 418B-17-1 and 418B-17-3) or claystone (Sections 418B-17-2, 418B-21-1, and 418B-21-2).

In Hole 418A, all samples fall in the poor or intermediate range. They are defined as pelagic and nannofossil clays from the Cenomanian to Aptian ages.

In Hole 418B, organic black clays (Sample 418B-28-1, 118 $\mathrm{cm}$ and Section 418B-30-1) with organic contents of 10.20 and 7.63 per cent, respectively, can be distinguished from the noncalcareous clays (Sample 418B-28-1, $101 \mathrm{~cm}$ and Section 418B-30-2) with 1.60 per cent or less, from nannofossil chalk sediments which belong to the intermediate range (Samples 418B-28-1, $106 \mathrm{~cm}$ and 418B-28-1, $113 \mathrm{~cm}$; and Section 418B-33-1), and also from some other clays (Sections 418B-28-2 and 418B-30-3).

\section{Carbon Analysis and Lithology}

If mineral and organic carbon analysis are considered together (Table 1), the studied samples can be related to the following types of lithology.

Very low mineral and low organic carbon contents defined the various green to red clays and claystones. A low mineral carbon and a higher organic content characterize the black clays and claystones. A medium mineral carbon and a medium organic content are typical for the nannofossil chalks. A high 


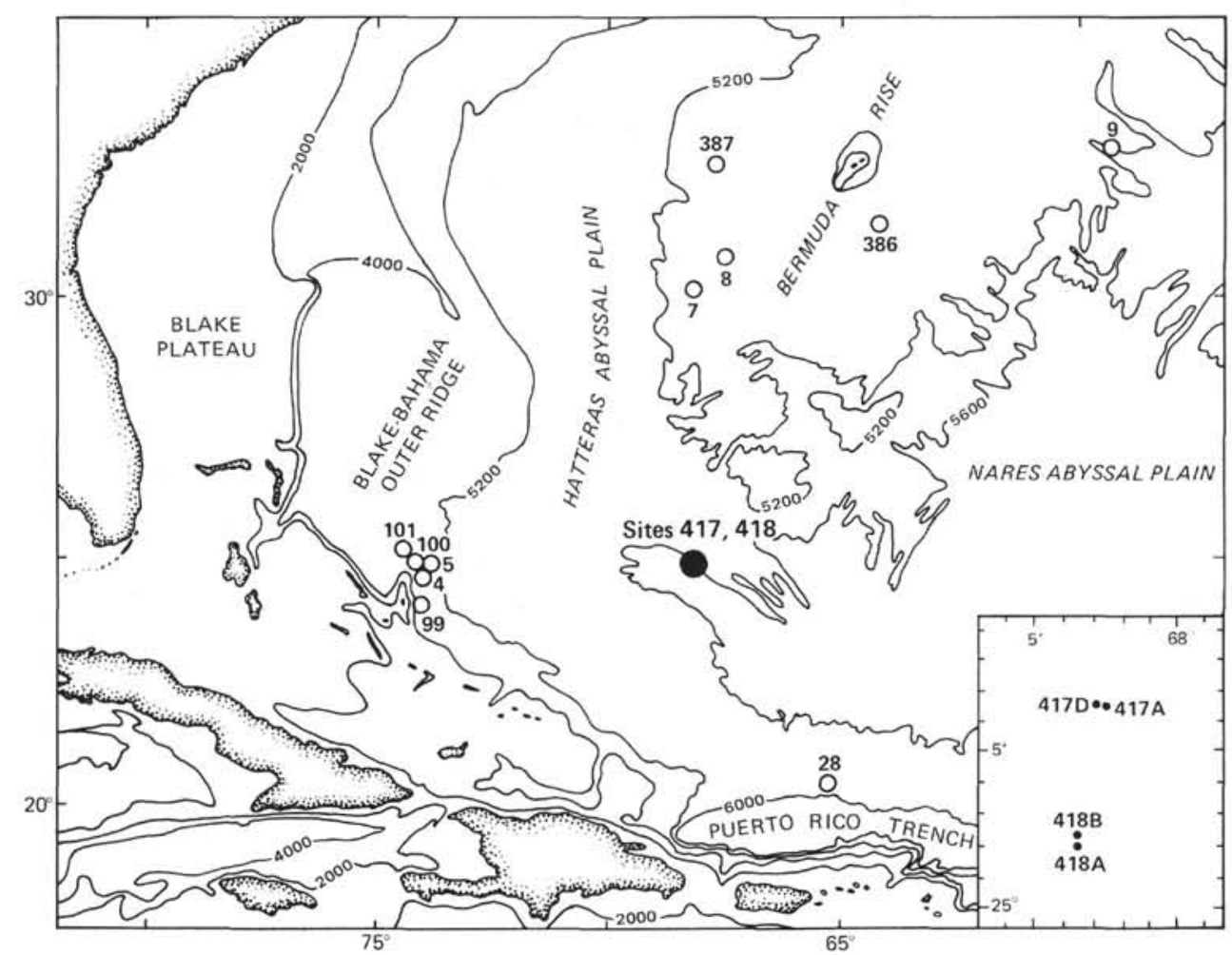

Figure 1. Location of DSDP Sites 417 and 418.

mineral carbon associated with a poor organic content defines the nannofossil limestone. To this can be added an intermediate type of association which was especially found when laminations or gradational contacts were present.

\section{Pyrolysis Assay and Organic Matter Characterization}

Pyrolysis (Espitalié et al., 1977) allows a characterization of the type and maturation of the sedimentary organic material. Figure 4 shows a plot of the values of hydrogen and oxygen indexes related to the weight of organic carbon (see also Table 2). These indexes allow a characterization of the organic matter in the same way as the Van Krevelen diagram $(\mathrm{H} / \mathrm{C}$ versus $\mathrm{O} / \mathrm{C}$ ratio) can be used for the isolated kerogen fraction (Tissot et al., 1974).

Preliminary pyrolysis was made upon raw samples. As contamination (probably by commercial hydrocarbons during the drilling) was detected after the examination of extracted hydrocarbon, pyrolysis was performed again on the extracted sample material. Only the latter data will be discussed hereafter (Table 2).

\section{Characterization of Organic Matter}

\section{Hole 417D}

As a rule, pyrolysis results from very low organic carbon content samples $(<0.15 \%)$ were considered of no significance in our study. They are designated in Table 2 by "no significant data." This interval corresponds to the zeolitic clays of the Upper Cretaceous and to the reddish brown or light colored claystones of the Albian to Aptian interval. Some of the latter are "burrowed throughout" (Sample 417D-19-1, $13 \mathrm{~cm}$ ) or located in "cyclic sedimentation with a turbiditic aspect", (Shipboard Report, Core Description) for Sections 417D-20-1 and 417D-20-2. The only nannofossil limestone (Section 417D-19-2) belongs to this same group.

All the organic-rich (i.e., $>3.6 \%$ carbon) sediments from Hole 417D, Sections 17-1, 17-3, 17-4, 18-1, 18-2, 19-1, and 21-3 show relatively high hydrogen indexes (227 to 416 ) combined with low oxygen indexes (70 and less). This is indicative of some marine (Type II) autochthonous organic matter mixed with an input of a more or less continental (Type III) and/or detrital origin.

In contrast, pyrolysis located the samples of Hole 417D, Sections 17-2, 21-1, and 21-2 in the nonmarine material area (Type III = humic compounds and higher plants) with low hydrogen indexes $(<100)$ and relatively high oxygen indexes.

\section{Hole 418A}

Insignificant pyrolysis results were again obtained on the organic lean sediments from Samples 418A-13-1, $42 \mathrm{~cm}$ and $418 \mathrm{~A}-13-2,4 \mathrm{~cm}(0.11 \%$ carbon or less $)$. Hydrogen and oxygen indexes for the two other samples (Section 418A-10-1 and Sample 418A-13-2, $91 \mathrm{~cm}$ ) fell in the area of the Type III reference path, i.e., of nonmarine organic material.

\section{Hole 418B}

The situation described for the Cenomanian to Aptian interval in Hole 417D was again encountered here. Thus, a marine influence mixed with continental input can be deduced for the organic matter of Samples 418B-28-1, $113 \mathrm{~cm}$ and 418B-28-1, $118 \mathrm{~cm}$ and Section 418B-30-1. In contrast, Samples 418B-28-1, $101 \mathrm{~cm}$ and 418B-28-1, $106 \mathrm{~cm}$ and Section 418B-30-2 can be referred to a nonmarine Type III material. The other sections (418B-33-1, 418B-30-3, and 418B-28-2) fall at an intermediate location where the Type III material would be dominant. 


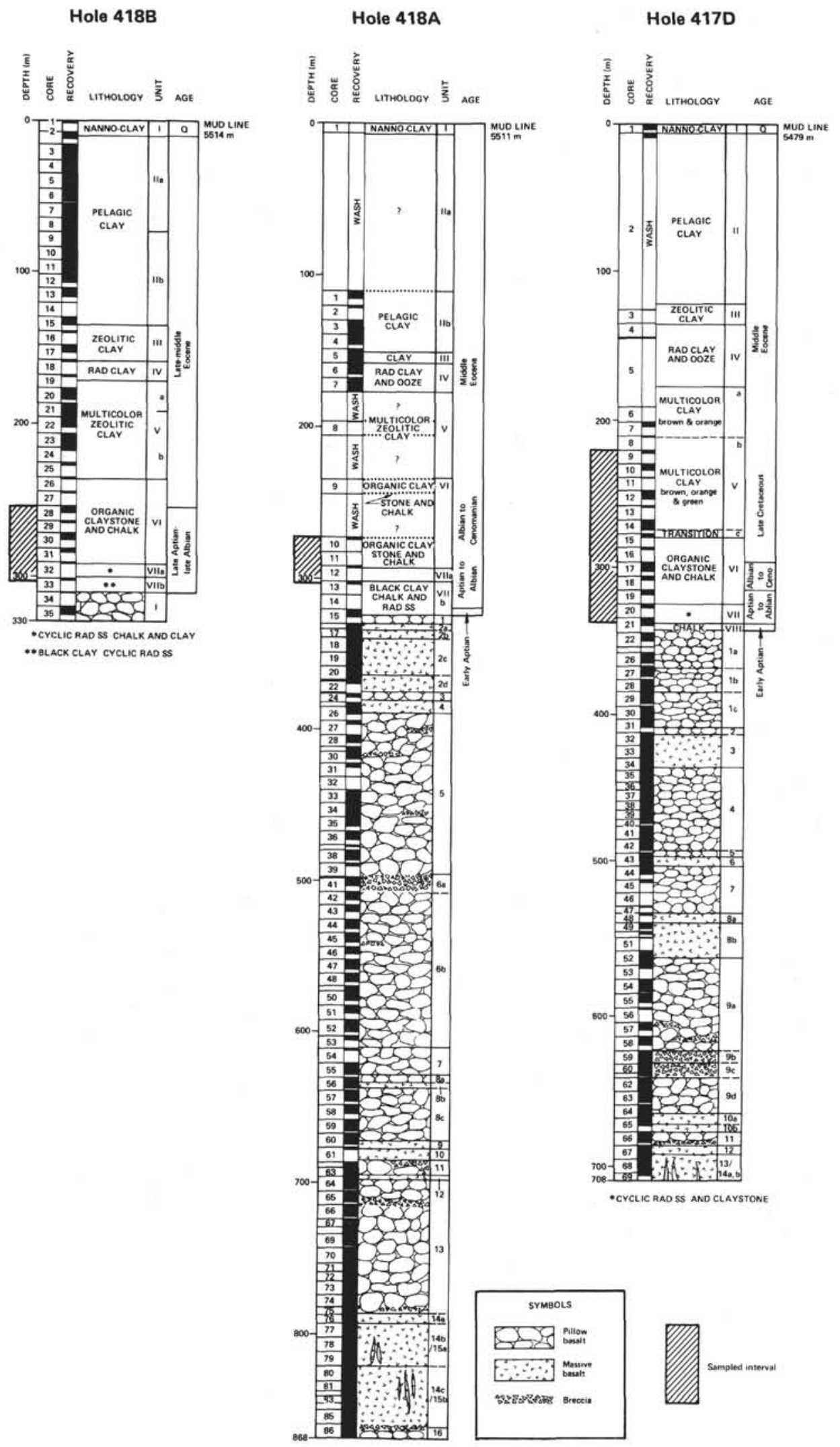

Figure 2. Stratigraphic location of sampled cores. 


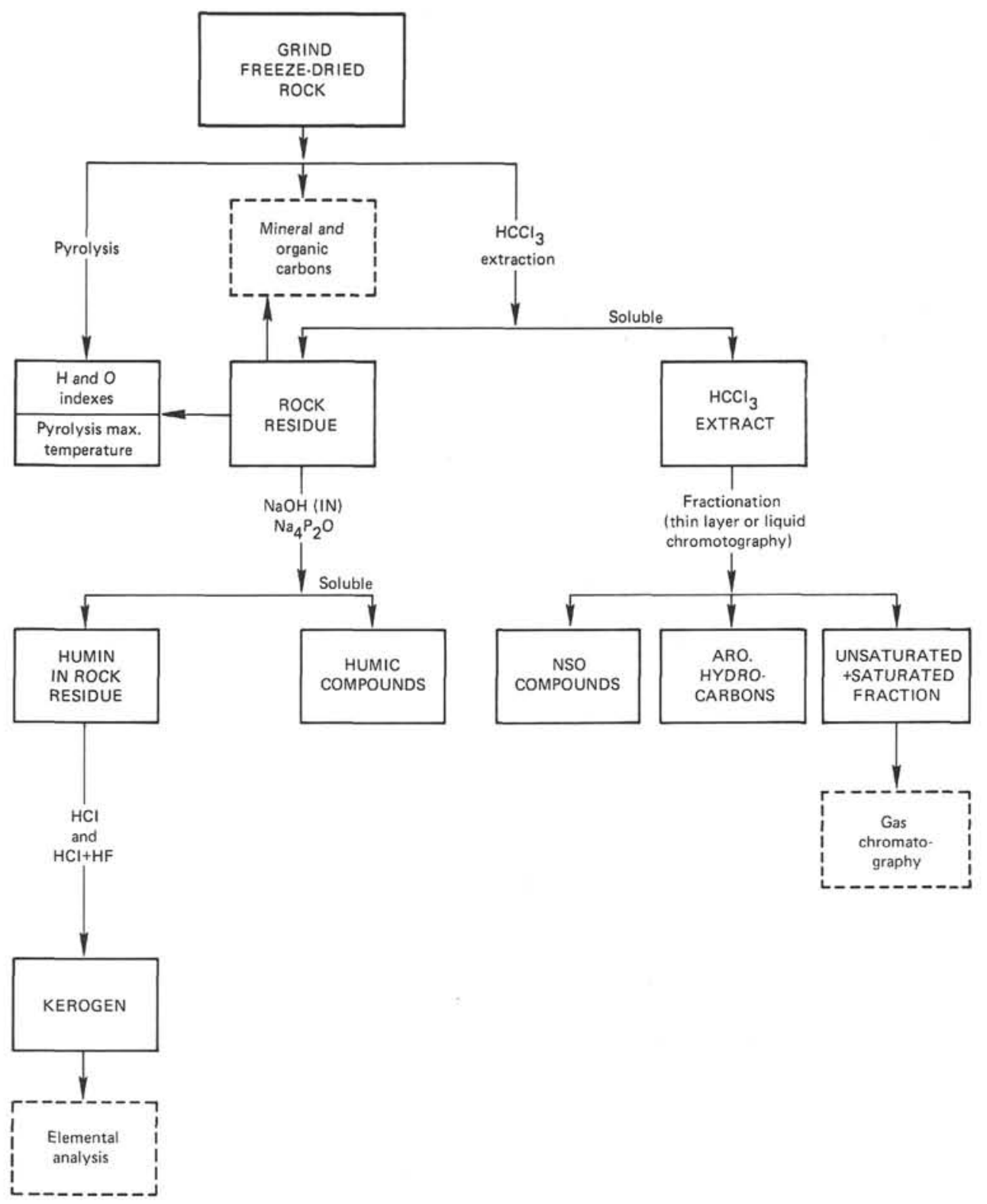

Figure 3. Schematic analytical procedures.

\section{Organic Maturity}

Temperature at the maximum of the pyrolysis peak during pyrolysis assays (Table 2) has a low range of $415^{\circ}$ to $434^{\circ} \mathrm{C}$. This is characteristic of immature organic material. Exceptions derive from low organic carbon and poor pyrolyzable samples where temperatures reached $450^{\circ} \mathrm{C}$ and more; higher maximum temperatures would be expected from reworked organic matter.

\section{Vertical Distributions}

The vertical distribution of hydrogen index related to weight of rock is now considered as a function of the organic carbon content (Table 2).

\section{Hole 417D}

Zeolitic clays of Late Cretaceous age (Cores 417D-9 to 417D-16) reveal a very poor content of residual organic

matter. In the upper part (Core 417D-17 to Section 417D-19-1) of the Cenomanian to Aptian interval, pyrolysis corresponds mainly to mixed marine autochthonous and continental organic matter inputs. Some organic matter having a low pyrolysis yield is present in the lower part of the interval (Cores 417D-19-1 to 417D-20-2). This organic matter corresponds to contemporaneous (and first cycle) material which belongs either to the light colored or to the reddish brown claystones; some are burrowed, others belong to cyclic layers of "turbiditic aspect." At the bottom of the series, in Samples 417D-21-1, $19 \mathrm{~cm}$ and 417D-21-2, $87 \mathrm{~cm}$ the marine fraction is replaced by a nonmarine and/or a detrital input. The change probably would be related to the cyclic sediments described as "with minor interlayers of claystone and dark claystone"' (Shipboard Report, Core Description). The last and deepest sample (Section 417D-21-3) also revealed some marine organic material. 
TABLE 1

Carbon Analysis Data and Lithology

\begin{tabular}{|c|c|c|c|c|}
\hline $\begin{array}{c}\text { Sample } \\
\text { (Interval in } \mathrm{cm} \text { ) }\end{array}$ & $\begin{array}{l}\text { Mineral } \\
\text { Carbon } \\
\text { (wt. \%) }\end{array}$ & $\begin{array}{l}\text { Organic } \\
\text { Carbon } \\
\text { (wt. \%) }\end{array}$ & Lithology & Age \\
\hline \multicolumn{5}{|l|}{ Hole 417D } \\
\hline $\begin{array}{l}9-2,72-73 \\
10-1,37-39 \\
10-1,72-74 \\
10-1,103-105 \\
10-2,85-87 \\
10-2,127-129 \\
10-3,74-76 \\
12-3,79-81 \\
13-1,74-76 \\
13-1,82-84 \\
13-2,8-10 \\
14-2,20-22 \\
14-5,51-53 \\
14-5,105-107 \\
15-1,28-30 \\
15-2,63-66 \\
16-1,52-55\end{array}$ & $\begin{array}{l}0.40 \\
0.68 \\
0.76 \\
0.76 \\
0.92 \\
0.48 \\
0.52 \\
0.56 \\
0.56 \\
1.00 \\
0.48 \\
0.60 \\
0.56 \\
0.64 \\
0.64 \\
0.00 \\
0.72\end{array}$ & $\begin{array}{l}0.11 \\
0.09 \\
0.10 \\
0.09 \\
0.08 \\
0.09 \\
0.10 \\
0.11 \\
0.07 \\
0.10 \\
0.10 \\
0.10 \\
0.09 \\
0.11 \\
0.11 \\
0.12 \\
0.13\end{array}$ & Multicolored zeolitic clays & $\begin{array}{c}\text { Late } \\
\text { Cretaceous }\end{array}$ \\
\hline $\begin{array}{l}17-1,122-126 \\
17-2,78-80 \\
17-3,16-18 \\
17-4,7-9 \\
18-1,76-77 \\
18-2,34-36\end{array}$ & $\begin{array}{l}2.16 \\
0.60 \\
6.04 \\
1.16 \\
0.68 \\
1.36\end{array}$ & $\begin{array}{l}3.70 \\
1.85 \\
4.62 \\
9.96 \\
8.27 \\
5.73\end{array}$ & $\begin{array}{l}\text { Claystone and clayey nannofossil chalk } \\
\text { Claystone } \\
\text { Nannofossil chalk } \\
\text { Black claystone } \\
\text { Black to brownish claystone }\end{array}$ & $\begin{array}{c}\text { Cenomanian } \\
\text { to } \\
\text { Albian }\end{array}$ \\
\hline $\begin{array}{l}19-1,13-15 \\
19-1,103-106 \\
19-2,83-85 \\
20-1,99-102 \\
20-2,97-99 \\
21-1,19-21 \\
21-2,87-89 \\
21-2,105-107 \\
21-3,68-70\end{array}$ & $\begin{array}{l}0.92 \\
1.46 \\
8.60 \\
4.00 \\
2.40 \\
1.52 \\
1.60 \\
1.80 \\
2.80\end{array}$ & $\begin{array}{r}0.15 \\
6.84 \\
0.13 \\
0.13 \\
0.10 \\
1.10 \\
2.04 \\
0.18 \\
10.44\end{array}$ & $\begin{array}{l}\text { Claystone } \\
\text { Black organic claystone } \\
\text { Nannofossil limestone } \\
\text { Reddish brown claystone } \\
\text { Cyclic sandstone to claystone with } \\
\text { minor interlayers of } \\
\text { claystone } \\
\text { dark organic claystone }\end{array}$ & $\begin{array}{l}\text { Albian } \\
\text { to } \\
\text { Aptian }\end{array}$ \\
\hline \multicolumn{5}{|l|}{ Hole 418A } \\
\hline $10-1,100-116$ & 0.48 & 1.84 & Dark gray pelagic clay & $\begin{array}{c}\text { Cenomanian } \\
\text { to Albian }\end{array}$ \\
\hline $\begin{array}{l}13-1,42-46 \\
13-2,4-7 \\
13-2,91-94\end{array}$ & $\begin{array}{l}1.32 \\
0.08 \\
0.32\end{array}$ & $\begin{array}{l}0.08 \\
0.13 \\
1.36\end{array}$ & $\begin{array}{l}\text { Red-brown nannofossil clay } \\
\text { Red-brown clayey nannofossil ooze } \\
\text { Green pelagic clay }\end{array}$ & $\begin{array}{l}\text { Albian } \\
\text { to } \\
\text { Aptian }\end{array}$ \\
\hline \multicolumn{5}{|l|}{ Hole 418B } \\
\hline $\begin{array}{l}28-1,101-103 \\
28-1,106-108 \\
28-1,113-115 \\
28-1,118-120 \\
28-2,35-37 \\
30-1,129-131 \\
30-2,10-12 \\
30-3,48-50 \\
33-1,59-61\end{array}$ & $\begin{array}{l}0.60 \\
4.16 \\
6.96 \\
1.20 \\
1.08 \\
0.80 \\
0.00 \\
1.08 \\
6.00\end{array}$ & $\begin{array}{r}1.52 \\
1.48 \\
4.33 \\
10.20 \\
3.84 \\
7.63 \\
1.60 \\
4.02 \\
4.46 \\
\end{array}$ & $\begin{array}{l}\text { Grayish green noncalcareous clay } \\
\text { Nannochalk to marl } \\
\text { Nannochalk } \\
\text { Organic black clay } \\
\text { Grayish green noncalcareous clay } \\
\text { Black clay } \\
\text { Light green clay } \\
\text { Light green clay and black clay } \\
\text { Olive-green-gray nannochalk }\end{array}$ & $\begin{array}{c}\text { Late } \\
\text { Albian } \\
\text { to } \\
\text { Late } \\
\text { Aptian }\end{array}$ \\
\hline
\end{tabular}

\section{Hole 418A}

Because of the poor sample recovery and drilling disturbance, the results from the four samples of the Cenomanian to Aptian interval were inconclusive, revealing either a nonmarine or a detrital organic matter. High temperatures of pyrolysis seem to indicate both reworked (Sample 418A13-2, $4 \mathrm{~cm}$ ) and first cycle organic material (Section 418A10-1 and Sample 418A-13-2, $91 \mathrm{~cm}$ ).

\section{Hole 418B}

A fluctuating marine input was observed in the series of Cores 418B-28 to 418B-33 (late Albian to late Aptian). Core 418B-28 presents a good example of the distribution of different organic matter types among various laminations.

Sample 418B-28-1, $101 \mathrm{~cm}$ contains alternating non-marine and reworked material and includes bioturbation (burrows).

Samples 418B-28-1, $106 \mathrm{~cm}$ and 418B-28-1,113 cm which contain faintly laminated sediments are related, respectively, to a nonmarine and to a mixed marine and nonmarine. Underlying Sample 418B-28-1, $118 \mathrm{~cm}$ is a noncalcareous black clay, which contains mixed material. The same characteristics are found for Sample 418B-30-1, $129 \mathrm{~cm}$

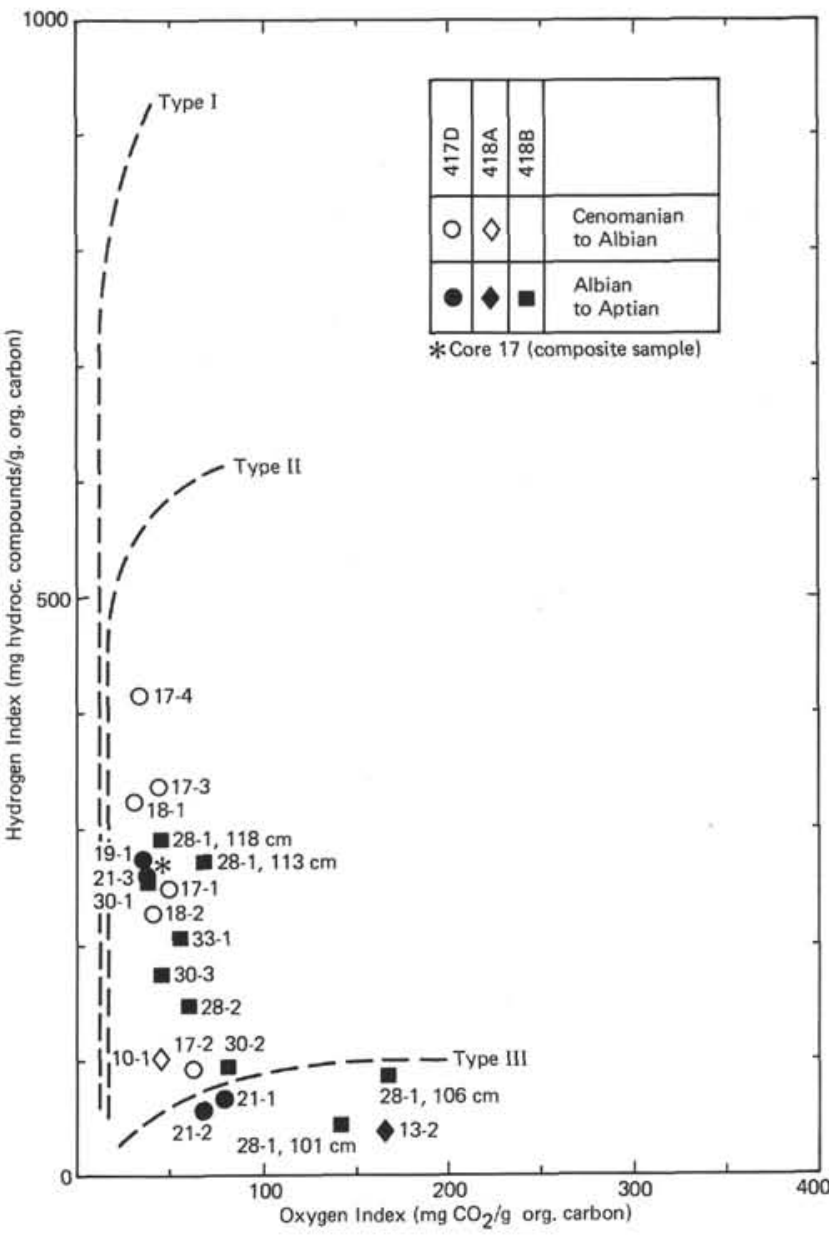

Figure 4. Pyrolysis assays. Hydrogen and oxygen indexes (data related to organic carbon).

which is a black clay, while Sample 418B-30-2, $10 \mathrm{~cm}$ where "flattened burrows" are mentioned, contains nonmarine organic material. Section 418B-30-3 yielded a mixed, marine and nonmarine organic material, as did Section 418B-33-1. Microlaminations could account for the composite origin of the latter.

\section{Comparison of Sites}

A most striking result was the rhythmic organic sedimentation for Cenomanian to Aptian sequences at Holes 417D and 418B.

Aquatic organic material of marine origin, generally well preserved, characterized the input of the Cenomanian to Aptian series. Continental inputs were rhythmically introduced in the èvironment. They were derived either from contemporaneous and well-preserved terrestrial material or from reworked or more-or-less altered sources. The latter was characteristic for the Albian to Aptian samples from Cores 418B-21 through 418B-19, and was exclusively present for the Upper Cretaceous samples from Cores 418B-16 to 418B-9. At Hole 418A, continental and detrital inputs are the only defined materials.

\section{Kerogen Fraction}

Kerogen elemental analysis was made on three composite samples from Hole 417D. Samples of Cores 417D-10 to 
TABLE 2

Sample Depths, Carbon and Pyrolysis Assay Data

\begin{tabular}{|c|c|c|c|c|c|c|c|c|c|}
\hline $\begin{array}{c}\text { Sample } \\
\text { (Interval in } \mathrm{cm} \text { ) }\end{array}$ & $\begin{array}{l}\text { Sub-Bottom } \\
\text { Depth } \\
\text { (m) }\end{array}$ & $\begin{array}{l}\text { Mineral } \\
\text { Carbon } \\
\text { (wt. \%) }\end{array}$ & $\begin{array}{l}\text { Organic } \\
\text { Carbon } \\
\text { (wt. \%) }\end{array}$ & $\begin{array}{l}\text { Hydrogen } \\
\text { Index } \\
\text { (mg hydroc. } \\
\text { compounds } \\
\text { related to } \\
\text { g of org. } \\
\text { carbon) }\end{array}$ & $\begin{array}{l}\text { Oxygen } \\
\text { Index } \\
\text { (mg CO} 2 \\
\text { related to } \\
\text { g of org. } \\
\text { carbon) }\end{array}$ & $\begin{array}{l}\text { Hydrogen } \\
\text { Index } \\
\text { (mg hydroc. } \\
\text { compounds } \\
\text { related to } \\
\text { g of rock) }\end{array}$ & $\begin{array}{l}\text { Oxygen } \\
\text { Index } \\
\text { (mg CO } \\
\text { related to } \\
\mathrm{g} \text { of rock) }\end{array}$ & $\begin{array}{c}\text { Pyrolysis } \\
\text { Tem- } \\
\text { perature } \\
\left({ }^{\circ} \mathrm{C}\right)\end{array}$ & Age \\
\hline \multicolumn{10}{|l|}{ Hole 417D } \\
\hline $\begin{array}{l}10-1,37-39 \\
10-1,72-74 \\
10-1,103-105 \\
10-2,85-87 \\
10-2,127-129 \\
10-3,74-76 \\
12-3,79-81 \\
13-1,76-76 \\
13-1,82-84 \\
13-2,8-10 \\
14-2,20-22 \\
14-5,51-53 \\
14-5,105-107 \\
15-1,28-30 \\
15-2,63-66 \\
16-1,52-55\end{array}$ & $\begin{array}{l}230.27 \\
230.62 \\
230.93 \\
232.25 \\
232.67 \\
233.64 \\
252.69 \\
258.94 \\
259.04 \\
259.78 \\
269.40 \\
274.21 \\
274.75 \\
277.58 \\
279.43 \\
287.32\end{array}$ & $\begin{array}{l}0.60 \\
0.68 \\
0.68 \\
0.80 \\
0.20 \\
0.40 \\
0.40 \\
0.24 \\
0.82 \\
0.36 \\
0.52 \\
0.48 \\
0.39 \\
0.56 \\
0.00 \\
0.58\end{array}$ & $\begin{array}{l}0.10 \\
0.12 \\
0.13 \\
0.10 \\
0.12 \\
0.10 \\
0.11 \\
0.09 \\
0.10 \\
0.11 \\
0.09 \\
0.09 \\
0.11 \\
0.13 \\
0.12 \\
0.11\end{array}$ & & & $\begin{array}{c}\text { no } \\
\text { significant } \\
\text { datab }^{\text {b }} \\
\text { (n. s. d.) }\end{array}$ & & & $\begin{array}{l}\text { Late } \\
\text { Creta- } \\
\text { ceous }\end{array}$ \\
\hline $\begin{array}{l}17-1,122-124 \\
17-2,78-80 \\
17-3,16-18 \\
17-4,7-9 \\
18-1,76-77 \\
18-2,34-36\end{array}$ & $\begin{array}{l}297.52 \\
298.58 \\
299.46 \\
300.87 \\
306.66 \\
307.74\end{array}$ & $\begin{array}{l}2.00 \\
0.46 \\
5.98 \\
1.08 \\
0.60 \\
1.02\end{array}$ & $\begin{array}{l}3.67 \\
1.82 \\
4.53 \\
8.78 \\
7.82 \\
5.38\end{array}$ & $\begin{array}{r}248 . \\
93 . \\
335 . \\
416 . \\
324 . \\
227 .\end{array}$ & $\begin{array}{l}50 . \\
62 . \\
43 . \\
35 . \\
31 . \\
42 .\end{array}$ & $\begin{array}{r}9.32 \\
1.82 \\
15.29 \\
36.74 \\
25.51 \\
12.34\end{array}$ & $\begin{array}{l}1.82 \\
1.13 \\
1.95 \\
3.05 \\
2.44 \\
2.24\end{array}$ & $\begin{array}{l}428 . \\
420 . \\
432 . \\
430 . \\
417 . \\
418 .\end{array}$ & $\begin{array}{c}\text { Cenom. } \\
\text { to } \\
\text { Albian }\end{array}$ \\
\hline $\begin{array}{l}19-1,13-15 \\
19-1,103-106 \\
19-2,83-85 \\
20-1,99-102 \\
20-2,97-99 \\
21-1,19-21 \\
21-2,87-89 \\
21-2,105-107 \\
21-3,68-70\end{array}$ & $\begin{array}{l}315.53 \\
316.43 \\
317.73 \\
325.99 \\
327.47 \\
344.19 \\
346.37 \\
346.55 \\
347.68\end{array}$ & $\begin{array}{l}0.90 \\
1.08 \\
8.20 \\
3.80 \\
2.00 \\
0.92 \\
1.20 \\
1.60 \\
1.98\end{array}$ & $\begin{array}{r}0.12 \\
6.46 \\
0.11 \\
0.13 \\
0.11 \\
1.04 \\
1.93 \\
0.16 \\
10.09\end{array}$ & $\begin{array}{r}67 . \\
58 . \\
\\
258 .\end{array}$ & $\begin{array}{l}79 . \\
70 . \\
38 .\end{array}$ & $\begin{array}{c}\text { (n. s. d.) } \\
17.56 \\
\text { (n. s. d.) } \\
\text { (n. s. d.) } \\
\text { (n. s. d.) } \\
.79 \\
1.20 \\
\text { (n. s. d.) } \\
26.49\end{array}$ & $\begin{array}{l}0.82 \\
1.35 \\
\\
3.83\end{array}$ & $\begin{array}{l}414 . \\
418 . \\
409 .\end{array}$ & $\begin{array}{l}\text { Albian } \\
\text { to } \\
\text { Aptian }\end{array}$ \\
\hline $0.0^{\mathrm{a}}$ & & 1.92 & 4.97 & 268. & 42. & 13.58 & 2.08 & 415. & \\
\hline \multicolumn{10}{|l|}{ Hole 418A } \\
\hline $10-1,100-116$ & 273.50 & 0.12 & 1.73 & 102. & 45. & 1.86 & .77 & 426. & $\begin{array}{c}\text { Cenom. } \\
\text { to } \\
\text { Albian }\end{array}$ \\
\hline $\begin{array}{l}13-1,42-46 \\
13-2,4-7 \\
13-2,91-94\end{array}$ & $\begin{array}{l}301.42 \\
302.54 \\
303.41\end{array}$ & $\begin{array}{l}1.40 \\
0.42 \\
0.62\end{array}$ & $\begin{array}{l}0.07 \\
0.11 \\
1.20\end{array}$ & 37. & 166. & $\begin{array}{r}\text { (n. s. d.) } \\
\text { (n. s. d.) } \\
0.46\end{array}$ & 1.99 & 434. & $\begin{array}{l}\text { Albian } \\
\text { to } \\
\text { Aptian }\end{array}$ \\
\hline \multicolumn{10}{|l|}{ Hole 418B } \\
\hline $\begin{array}{l}28-1,101-103 \\
28-1,106-108 \\
28-1,113-115 \\
28-1,118-120 \\
28-2,35-37 \\
30-1,129-131 \\
30-2,10-12 \\
30-3,48-50 \\
33-1,59-61\end{array}$ & $\begin{array}{l}254.41 \\
254.46 \\
254.53 \\
254.58 \\
255.25 \\
273.69 \\
274.00 \\
275.88 \\
301.59\end{array}$ & $\begin{array}{l}0.76 \\
4.40 \\
6.88 \\
1.00 \\
1.32 \\
0.40 \\
0.00 \\
0.80 \\
6.00\end{array}$ & $\begin{array}{r}1.52 \\
1.44 \\
4.34 \\
10.14 \\
3.84 \\
7.48 \\
1.60 \\
3.97 \\
4.38\end{array}$ & $\begin{array}{r}43 . \\
84 . \\
270 . \\
289 . \\
146 . \\
255 . \\
91 . \\
171 . \\
203 \text {. }\end{array}$ & $\begin{array}{l}142 . \\
167 . \\
68 . \\
45 . \\
60 . \\
34 . \\
82 . \\
45 . \\
56 .\end{array}$ & $\begin{array}{r}0.82 \\
1.27 \\
11.84 \\
29.64 \\
5.71 \\
19.09 \\
1.56 \\
6.97 \\
9.17\end{array}$ & $\begin{array}{l}2.16 \\
2.41 \\
2.95 \\
4.54 \\
2.30 \\
2.58 \\
1.31 \\
1.80 \\
2.44\end{array}$ & $\begin{array}{l}411 . \\
412 . \\
420 . \\
420 . \\
425 . \\
420 . \\
425 . \\
423 . \\
412 .\end{array}$ & $\begin{array}{c}\text { Late } \\
\text { Albian } \\
\text { to } \\
\text { Late } \\
\text { Aptian }\end{array}$ \\
\hline
\end{tabular}

${ }^{\text {a }}$ Cores $17-1$ to $17-4$.

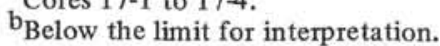


417D-14 were combined to make up one sample; the two other composite samples came from Cores 417D-17 and 417D-21.

The preparation used $\mathrm{HCl}+\mathrm{HF}$ acidic treatment under a nitrogen atmosphere. The data are plotted on a Van Krevelen diagram (Figure 5) and compared to (Table 3) the three reference kerogen evolution paths of Types I, II, and III (Tissot et al., 1974). No kerogen fraction was found for the first mentioned Upper Cretaceous sediments (from Cores $417 \mathrm{D}-10$ to $417 \mathrm{D}-14$ ). This is thought to be due to the low content of organic carbon indicating a kerogen fraction, too small to be isolated. For the two other samples, the kerogen elemental ratio values are located above the hydrogen-poor Type III trend. Thus, they can be considered a mixture of Type II and III material. The same picture was obtained when the pyrolysis data for the Core 417D-17 composite sample are considered (Figure 4): the sample was located in an intermediate position between the extreme Sections 417D-17-4 and 417D-17-2, and close to the medium 417D-17-1 sample; the weight ratio for Hole 417D Section $17-1: 17-2: 17-3: 17-4$ was 5:6:7:6 grams.

\section{Chloroform Extracts}

Seventeen samples from Hole 417D were studied and their extracts fractionated by thin-layer chromatography (Huc et al., 1976). They were taken from the Upper Cretaceous (Cores $417 \mathrm{D}-10$ to $417 \mathrm{D}-16$ ) and from the Cenomanian to Aptian interval (Sections 417D-17-1 to 417D-17-4, 417D-18-1 to 417D-18-2, 417D-19-1, and 417D-21-1 to 417D-21-2).

Saturate + unsaturate fraction from five samples (Cores 10 , $13,15,19$, and 20 of Hole 417D) were examined by mass spectrometry and show a very low content of polycyclics ( 3 cycles and more) and, concomitantly, a content of alkanes ( $50 \%$ and more) that is abnormally high for immature organic matter (Table 4). Moreover, the chromatogram distribution is noticeably constant for all the samples considered. The normal alkanes are largely diluted by iso-alkanes and cyclo-alkanes with few rings; chromatograms always present a regular climb of the base line along the $\mathrm{C}_{15}$ to $\mathrm{C}_{30} n$-alkanes interval. The same chromatographic distribution was found for the saturated + unsaturated fraction of a cable grease used when coring aboard the Glomar Challenger (Figure 6). It reasonably can be inferred that chloroform extracts of the studied samples are not representative of their indigenous organic matter. The same conclusion was made for the composite sample of sediments from Hole 418A.

\section{CONCLUSIONS}

The organic matter examined in the sedimentary sequences of Early Cretaceous age which overlay the basalt in Holes $417 \mathrm{D}, 418 \mathrm{~A}$, and $418 \mathrm{~B}$ was in part of aquatic origin. This was especially true for black clays and claystones. At the same time, materials of continental or detrital origin were rhythmically introduced in the marine environment. A change was observed for the overlying Upper Cretaceous sediments, in which the detrital organic material prevailed.

\section{ACKNOWLEDGMENTS}

The authors are indebted to Dr. C. Cornford, KFA, Jülich, for his comments and for reviewing this paper.

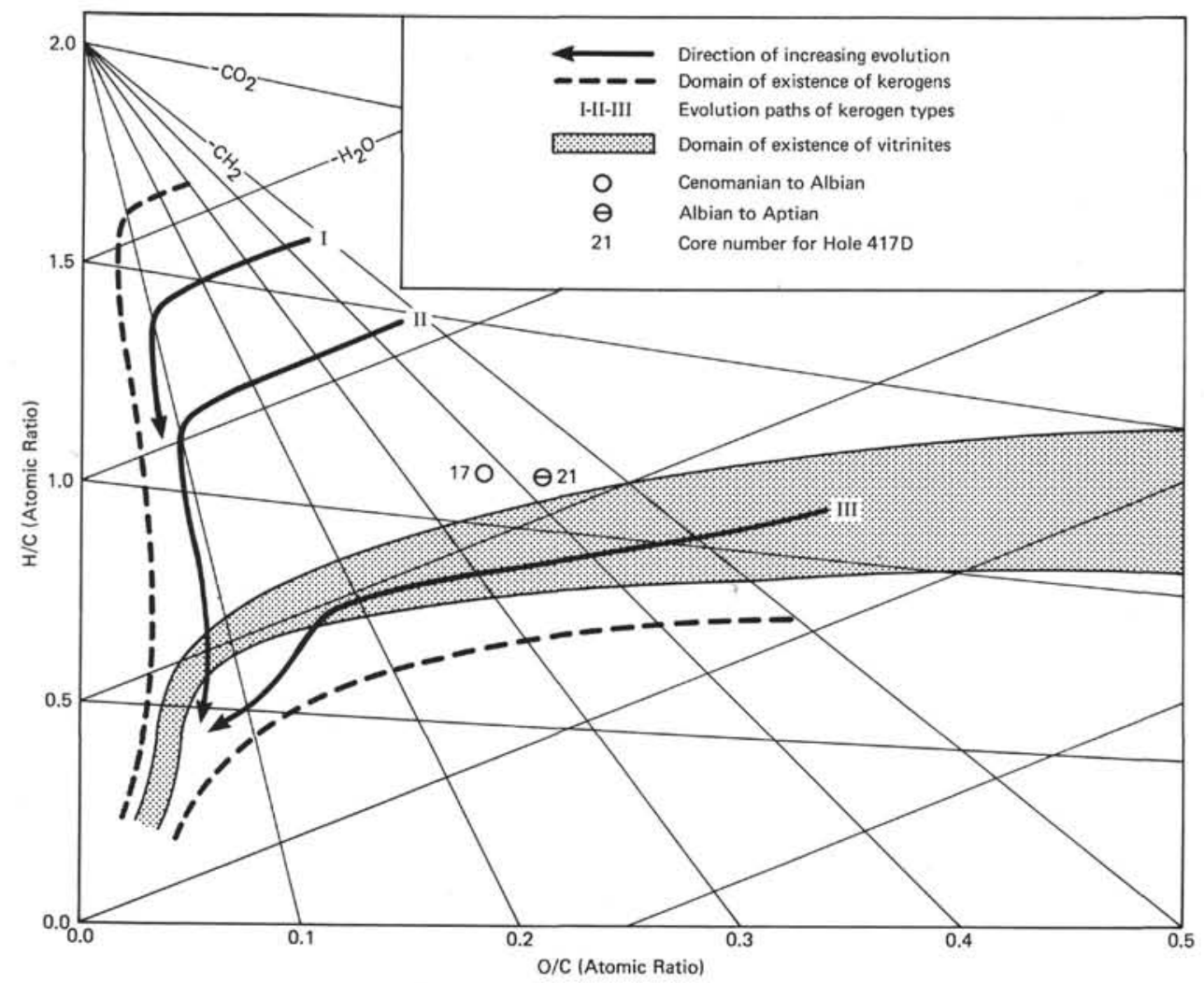

Figure 5. $\mathrm{H} / \mathrm{C}$ and $\mathrm{O} / \mathrm{C}$ diagram of kerogen. 
TABLE 3

Elemental Composition and Ash Content of Kerogens

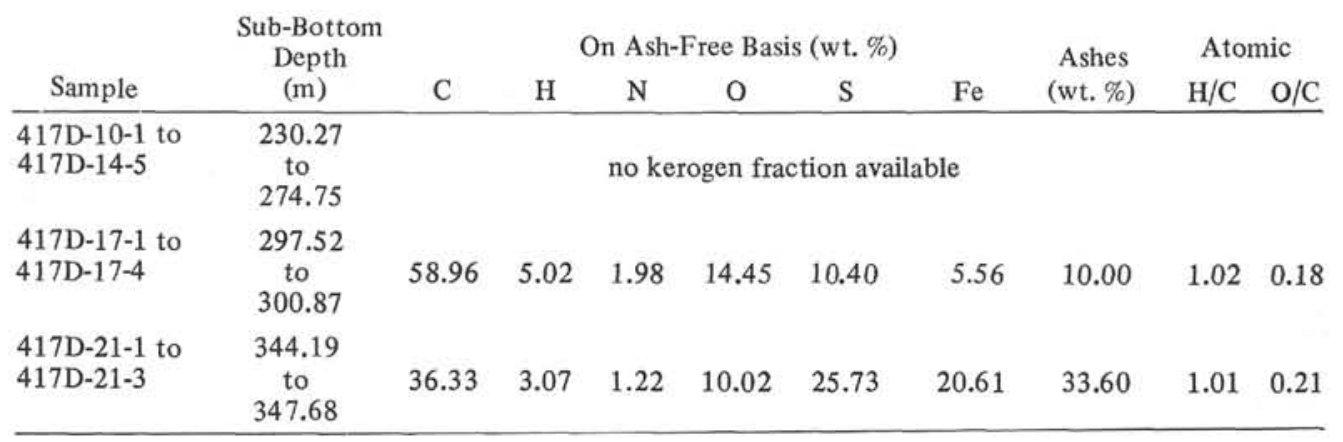

TABLE 4

Mass Spectrometry of Saturated + Unsaturated Fraction of Chloroform Extracts in Cores 417D-10 and 417D-19, (Distribution by Number of Rings (vol. \%)

\begin{tabular}{|c|c|c|c|c|c|c|c|c|}
\hline & & & $\begin{array}{l}\text { turate } \\
\text { Nur }\end{array}$ & $\begin{array}{l}1+\text { Un } \\
\text { aber of }\end{array}$ & $\begin{array}{l}\text { atur: } \\
\text { Ring }\end{array}$ & $\begin{array}{l}\text { ed F } \\
\text { (vol }\end{array}$ & $\begin{array}{l}\text { ction } \\
\text { b) }\end{array}$ & \\
\hline & (Interval in $\mathrm{cm}$ ) & 0 & 1 & 2 & 3 & 4 & 5 & 6 \\
\hline 劳 & $\begin{array}{l}417 \mathrm{D}-10-1,37 \text { and } 103 \\
417 \mathrm{D}-10-2,85 \text { and } 127 \\
417 \mathrm{D}-10-3,74\end{array}$ & 51.0 & 20.1 & 14.4 & 6.8 & 4.0 & 1.5 & 2.0 \\
\hline 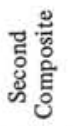 & $\begin{array}{l}417 \mathrm{D}-19-1,13 \\
417 \mathrm{D}-19-1,103\end{array}$ & 51.5 & 19.0 & 13.6 & 7.1 & 4.5 & 1.8 & 2.4 \\
\hline
\end{tabular}

\section{REFERENCES}

Deroo, G., Herbin, J.P., Roucaché, J., and Tissot, B., in press (a). Organic geochemistry of some organic rich shales from Site
397A; Leg 47A, Eastern North Atlantic. In Ryan, W.B.F., von Rad, U., etal., Initial Reports of the Deep Sea Drilling Project, $\mathrm{v}$. 47, Part 1: Washington (U.S. Government Printing Office). , in press (b). Organic geochemistry of Cretaceous shales from Site 398; Leg 47B, Eastern North Atlantic. In Ryan, W.B.F., Sibuet, J.C., et al., Initial Reports of the Deep Sea Drilling Project, v. 47, Part 2: Washington (U.S. Government Printing Office).

Espitalié, J., Laporte, J.L., Madec, M., Marquis, F., Leplat, P., Paulet, J., and Boutefeu, A., 1977. Méthode rapide de caractérisation des roches mères, de leur potentiel pétrolier et de leur degré d'évolution, Rev. Inst. Franç. Pétrole, v. 32, p. 23-42.

Huc, A.Y., Roucaché, J., Bernon, M., Caillet, G., and Da Silva, M., 1976. Application de la chromatographie sur couche mince à l'étude quantitative et qualitative des extraits de roche et des huiles, Rev. Inst. Franç. Pétrole, v. 31, p. 67-98.

Tissot, B. Durand, B., Espitalié, J., Combaz, A., 1974. Influence of the nature and diagenesis of organic matter in the formation of petroleum, Am. Assoc. Petrol. Geol. Bull., v. 58, p. 499-506. 
a.
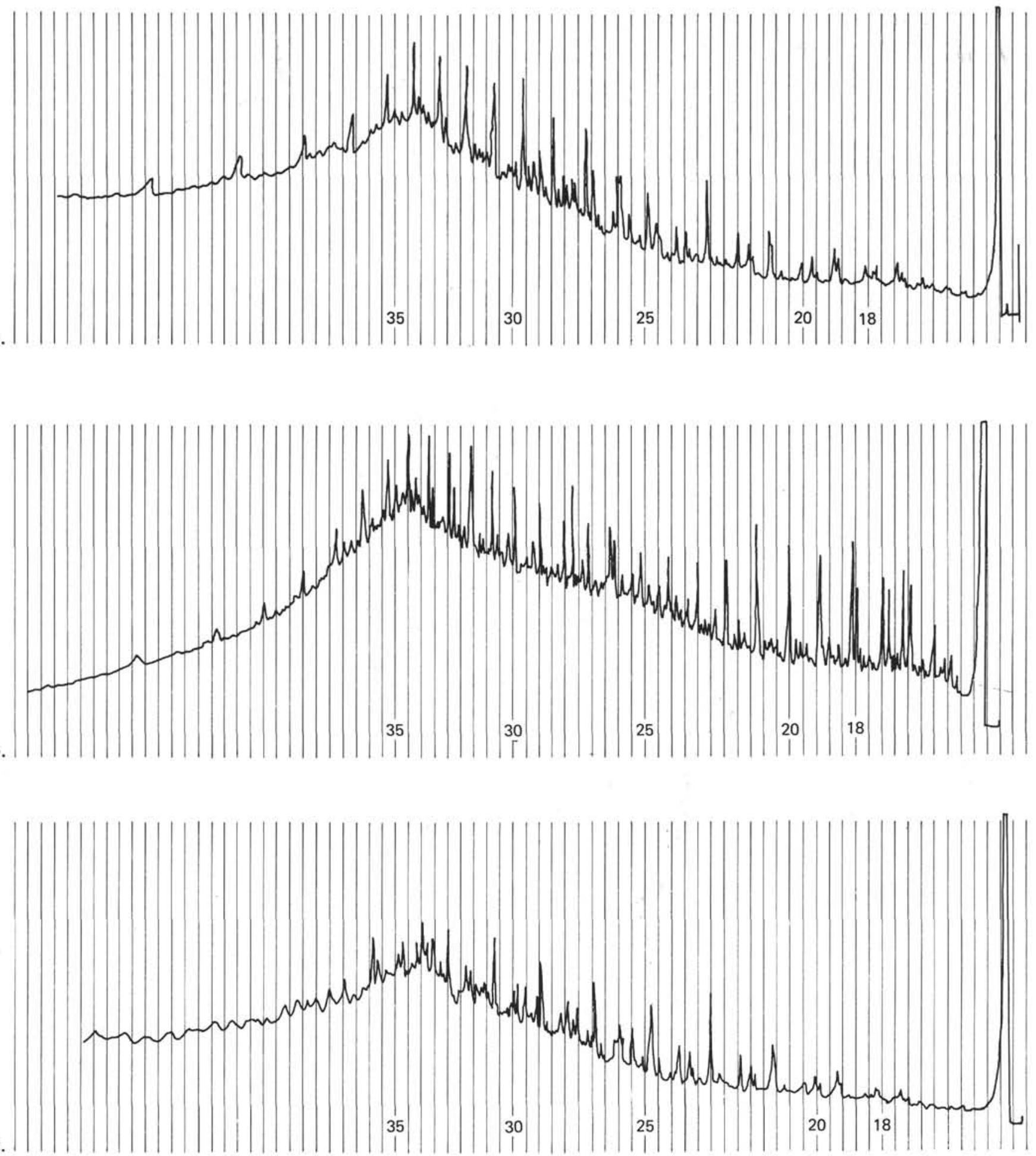

Figure 6. Chloroform extracts. Gas chromatography of saturated + unsaturated fraction. (a) Sample 417D-10-1, $72 \mathrm{~cm}$. (b) Cable grease, used on Glomar Challenger. (c) Sample 417D-19-1, $103 \mathrm{~cm}$. 